\title{
Life Cycle Assessment of Environmental ImpactsofUsing Concrete orTimber toConstruct aDuplex Residential Building
}

\author{
Anthony Nkem Ede ${ }^{1}(\mathrm{PhD})$, Samuel Olusegun Adebayo ${ }^{1}$, Emmanuel \\ Ikechukwu Ugwu ${ }^{1}$ and ChidoziePraiseGod Emenike ${ }^{1}$ \\ ${ }^{1}$ Department of Civil Engineering, College of Science and Technology, Covenant University, Canaan Land, Km \\ 10, Idiroko Road, P.M.B. 1023 Ota, Ogun State, Nigeria
}

\begin{abstract}
Traditionally, the choice of construction materials depended principally on the strengths of materials, cost of material, availability of materials, simplicity of erection, aesthetics and technical expertise available to the society. This meant that little attention was paid to the environment impacts of materials adopted for civil construction. After centuries of speedy advancement accompanied by deteriorating ecosystem as evidenced by the global climate change and the accompanying gap between the rich and the poor, the world is becoming more conscious of the ecosystem and the future of mankind. This has led to the growing quest for sustainable development. In the more recent years, environmental and sustainability factors are becoming compelling factors in the choice of construction materials. Researches focused on materials for affordable houses for the increasing low income masses are on the increase. This research focuses on the environmental impact performance of concrete and timber applied to a modest duplex residential building. It explores using Athena Impact Estimator software to model the greenhouses gases expressed in terms of carbon dioxide equivalents, sulphur dioxide equivalents, phosphate equivalents and ethane equivalents potentials obtainable from using concrete or timber to build a duplex residential building. From the various results obtained, it is very evident that timber construction is more eco-friendly in terms of carbon emission reduction which translates to reducing global warming, thermal insulation and energy efficiency. This will be helpful in making choice for building materials to be adopted for affordable houses developing countries.
\end{abstract}

Keywords: Affordable Homes, Concrete, Environmental Impact, Global Warming, Timber

\section{Introduction}

Over the years, the choices of building materials have always generated conflicts in the construction industry between the clients, architects and the design engineers. Preferable choices are based principally on the strengths of materials, cost of material, availability of materials, ease of erection, aesthetics and technical expertise available to the society. Although the traditional motivations for choices of materials continue to be the same over successive years, the technological advancement made in every new era depends mostly on how these materials are combined to the advantage of the society in terms of safety, economy and functionality of built structures [1]. In the more recent years, environmental and sustainability factors are becoming compelling aspects in the choices of construction materials.

Worldwide, concrete is one of the greatest inventions in the field of construction engineering. Nevertheless, concrete is known for its low tensile strength and as such it was limited in its utilization in its earlier years of its invention. The combination of steel reinforcement to the concrete compensated for the tensile weakness of concrete. Steel notably will give way due to buckling when subjected to compressive stresses. Both concrete and steel provide complementary support to each other compensating for the weaknesses in the properties of each material [2].The composite product of concrete and steel reinforcement in the form of reinforced concrete has been the most important materials used in the construction of complex structural members around the globe.

On the hand, there are possibly more residential buildings constructed with wood than any other structural material in the world today, especially in the advanced nations. Many of these buildings are single-family residences, mostly bungalows or single storied buildings but many larger apartment dwellings as well as business and industrial buildings also use wood framing. The use of timber in the construction industry has both economic and aesthetic appeal to the designer as well as the clients. The ability to construct timber structures with a minimal amount of specialized tools and equipment has made timber structures more economical in comparison with other building materials [3].Timber is natural occurring, and it is often utilized in the construction and building industry since it can be found in large quantities in the tropical rain forests of every part of the world. Timber has been used since pre historic times, and building materials formed from timber can be dated back to as far as 400,000 years ago making timber the most common and more widely known building material globally, as it can be used for construction of walls, roof members, floors as well as other household 
amenities [4]. The extent of its usage by professionals in the building industry was determined by their acceptance and perception of the material. With the proven good structural property, timber never attained anywhere near its full potential in the building industry in the developing nations. This was due to the fact that many clients, architects, and designer engineers never appreciate wood as being able to compete favourable with the rivals such as concrete, steel or masonry. Lack of adequate expertise and sufficient skill needed to fully realize the potential of timber as a building material has hindered better understanding of durability and structural reliability of timber as a structural material in different part of the world [5]. As adequate knowledge of engineering materials is vital for structural design, various researches carried out in the recent years have made available all-inclusive information and data on structural properties of timber and timber related products. Considerable knowledge and information has been gained on its important properties and their effects on structural design and service behaviour and thus, a better understanding of the physical characteristics of wood which aids the building of safe timber structure has been attained in the advanced World[6].

In Nigeria, the two basic building materials commonly adopted for construction of residential houses are concrete and timber with concretebeing the most common construction materials adopted for residential buildings in Nigeria. The high demand for concrete material technology has led to high cost of construction in Nigeria. Concrete is adopted in the form of framed reinforced concrete structures with concrete-sand crate block walls for buildings of greater heights in the urban areas and concrete-sand crate block masonry for mono storey buildings in the country sides. Timber is often adopted for lightweight construction in the rural areas and in particular in the riverine villages. Timber is rarely utilized, but readily available and as such designers should begin to consider lightweight and cost effective alternatives to concrete that is gradually becoming expensive to build with. This brings about the need toanalysebetter concrete and timber as to give the designer a choice when considering choices of construction materials for affordable residential buildings. Incomparison with the time and resources devoted to steel and reinforced-concrete design, timber design is not given sufficient attention in most colleges and universities, and as such timber design in Nigeria is very scarce in relation to steel and reinforced concrete designs as evidenced in the vast majority of buildings seen in the country. In most cases, the application of timer in building construction in Nigeria is based more on experience and rudimental approximations without any sound engineering design principle. Moreover, concrete has been a prevalent construction material for most residential buildings in worldwide but due to its cost of realisation, provision of affordable residential apartments for the low income earner has been a difficult challenge in most developing countries including Nigeria. It is therefore of necessity to provide alternative building materials that will not only rival concrete in cost, but also serve as a viable competitor in terms of sustainability, maintenance, constructability and client satisfaction in all necessary ramifications. With this in mind, timber has been selected as the alternative material to rival concrete in the Nigerian building sector and this research compares both materials on the sustainability background as to provide the Nigerian client, architect, engineers and policy makers' reasons to choose one material over the other for future construction needs. This research focuses on the environmental impact performance of both concrete and timber materials used for the construction of a duplex residential building.

\section{Material And Method}

Nigeria is an over populated nation and for this reason, the need to provide adequate residential buildings for the masses cannot be over emphasized. This need has resulted in a huge increase in building construction projects in all parts of the country. The most common and widely utilized material for residential building construction is undoubtedly concrete. Concrete constituent materials are relatively expensive, and the labour that accompanies its usage doesn't come cheap as well. This is why it is important for alternative building materials to be introduced into the nation's building sector in order to have a better and cheaper solution to the shelter problem shrouding the nation. In the design and construction process of any building, the designer must ensure that the adequate requirements necessary for the structure to benefit its user must be accounted for. Due to this, a balance must be struck as regards the social, environmental and economic aspects of such projects [7].

In building projects, the environmental impact of using one building material over another should be adequately considered, as construction processes as well as the mere operation and existence of buildings have significant impact on the environment. The building construction industry is known to be responsible for the annual consumption of approximately $40 \%$ of the aggregates used for concrete (raw stone, gravel, and sand) globally with about $25 \%$ of fresh un-seasoned wood. Global energy usage is not left out, as $40 \%$ also is consumed by buildings industrywith about $16 \%$ of global water usage is for building works [8]. The environmental impact of a material is quantified by the volume of carbon dioxide emitted and the amount of energy consumed during utilization. Below, we will consider the known effects of concrete material and timber materials separately. 
Life Cycle Assessment Of Environmental Impacts Of Using Concrete Or Timber To Construct A...

\subsection{Environmental impact of Concrete material}

During utilization and operation of concrete materials, energy is consumed efficiently. However, most of the energy is consumed during maintenance and post construction works. Concrete is readily available in Nigeria as there are vast numbers of cement producing industries. This makes transportation easier and thus carbon emissions resulting from long distance transportation is greatly minimized. Concrete can also be recycled to a minimum extent, and this provides not only a check on the greenhouse effect, but also provides an economic solution [9]. These facts notwithstanding, there exist many types of environmental impacts that need to be evaluated. Some of the environmental impacts to be determined include: pollution, thermal mass, carbon dioxide emissions, ozone depletion potential and global warming potential.

The impact of concrete on pollution can be of different types and affects different phases of concrete handling. During the production of cement, $240 \mathrm{~g}$ of sulphur dioxide and approximately $6000 \mathrm{~g}$ of nitrogen oxide is produced per tonne of cement. In concrete production, water is consumed significantly and thus liquid effluents are unavoidable. $1 \mathrm{~m}^{3}$ of concrete produces between 1500 and 3000 litres of alkaline effluents.

On thermal mass concrete structures have high level of thermal mass i.e. concrete has the capability of storing up thermal energy and dissipating it later in time. This makes concrete efficient in energy consumption, and thus greenhouse effects are reduced with comfort and conduciveness available to its user [7]. The foremost benefit of using concrete as regards efficiency in energy usage in buildings is its high thermal mass which leads to thermal stability. The effect of the thermal mass in concrete includes: regulation of internal temperature, reduction in energy used for both cooling and heating, reduction in general energy costs of buildings and all these leads to an overall cut in $\mathrm{CO}_{2}$ emissions and green house effects.

For carbon dioxide emissions,concrete is the most used engineering material globally and as such, it is responsible for approximately 5\% of global carbon dioxide emissions [10]. The cement in concrete also has significant impact on $\mathrm{CO}_{2}$ emissions as $900 \mathrm{~kg}$ of carbon dioxide is generated per tonne of cement manufactured [11]. This results in approximately $410 \mathrm{~kg} / \mathrm{m}^{3}$ of $\mathrm{CO}_{2}$ being generated as a tonne of concrete is produced [12].

\subsection{Life Cycle Assessment of concrete}

The environmental impact of a building is often neglected in this part of the country, but the performance of a building with respect to life cycle assessment should not be over looked as buildings make up a huge component of manmade infrastructures available. When a building is in operation, more energy and greenhouse gases are dissipated than during the construction stage[13]. Thus, in order for a true analysis of the environmental impact of the building materials to be examined, both the construction and operations stages of the building process must be considered, taking into account the full life span of such building. The indicators used for concrete are ozone depletion potential, global warming potential, smog potential, eutrophication potential and acidification potential.The ozone depletion potential (ODP) of a substance is the relative amount of degradation or depletion the particular substance can have on the ozone layer.Global-warming potential (GWP) is a measure of how much heat a greenhouse gas traps in the atmosphere.

\subsection{Environmental impact of timber material}

The demand for timber for various purposes, has moved a lot of machines and people into most forests. The effect of this should not be underestimated as it as it affects the ecosystem. In most developing and under developing nations, low consideration is given to this aspect even as global climate change-induced consequences form part of the principal challenges confronting mankind in the recent years [14].Though theimpact might appear in minute scale, the ripple effect on the long run can be devastating. Timber is a natural occuring material, and it has been shown to be a 'greener' building material in relation to other conventional ones. Some of the factors to be considered as regards environmental impact are pollution, solid waste and embodied energy. During the production of timber, waste is generated as by-products and can have significant effects on the environment. Pollution is of different kinds, and the contribution of timber on the various types of pollutioncan be of different forms. During the production stage of timber, less Carbon dioxide, monoxide and sulfur dioxide is released when compared to other building materials. Forests generally reduce the amount of sulfur and nitrogen oxide present in the atmosphere, making timber an environmentally good material, [15].

For solid waste generation,the amount of solid waste generated from the timber construction site is as a result of material usage by the builder. This waste can be recycled easily into other timber products such as particle boards, fibre boards or even as fuel or fire wood. Considering embodied energy, timber products either softwood or hardwood requires the lowest production energy than any other major building material [16], [7]. From Table 1 , it can be observed that timber is the only material out of the selected building materials that stores atmospheric carbon, making it of great benefit in terms of reducing the greenhouse effect. The carbon dioxide released during the process of fabrication and production is also absorbed by the timber material. Also, from Table2, it can be seen that less energy is used in timber fabrication in comparison with other materials. 
Table 1: Carbon consumption in common building materials [16]

\begin{tabular}{|l|l|l|l|}
\hline Material & $\begin{array}{l}\text { Carbon released } \\
(\mathrm{Kg} / \mathrm{t})\end{array}$ & $\begin{array}{l}\text { Carbon released } \\
\left(\mathrm{Kg} / \mathrm{m}^{3}\right)\end{array}$ & $\begin{array}{l}\text { Carbon stored } \\
\left(\mathrm{Kg} / \mathrm{m}^{3}\right)\end{array}$ \\
\hline Rough Sawn timber & 30 & 15 & 250 \\
\hline Steel & 700 & 5320 & 0 \\
\hline Concrete & 50 & 120 & 0 \\
\hline Aluminium & 8700 & 22000 & 0 \\
\hline
\end{tabular}

Table 2: Energy usage in common building materials [16]

\begin{tabular}{|l|l|l|}
\hline Material & $\begin{array}{l}\text { Fossil fuel energy } \\
(\mathrm{MJ} / \mathrm{kg})\end{array}$ & $\begin{array}{l}\text { Fossil fuel energy } \\
\left(\mathrm{MJ} / \mathrm{m}^{3}\right)\end{array}$ \\
\hline Rough Sawn timber & 1.5 & 750 \\
\hline steel & 35 & 266000 \\
\hline Concrete & 2 & 4800 \\
\hline Aluminium & 435 & 1100000 \\
\hline
\end{tabular}

\subsection{Life Cycle Assessment of timber}

From the LCA reports and findings gotten by the Foretsry products division of the Food and Agriculture Organization of the United Nations (F.A.O) in the year 2002 [18], the ecological advantage of chosing wood as a building material over other materials were showcased. The indicators used are:Global Warming Potential (GWP) in $\mathrm{kg} \mathrm{CO} 2$ equivalents, Acidification Potential (AP) in $\mathrm{kg} \mathrm{SO} 2$ equivalents, Eutrophication Potential (EP) in kg phosphate equivalents, Photochemical Ozone Creation Potential (POCP) in $\mathrm{kg}$ ethane equivalent [19].Though the results from this report are not based on the Nigerian building industry, it however gives a good idea and knowledge of the benefits of timber in terms of sustainability. In the report, a comparison was made between three buildings materials (Concrete, wood and steel) used for a shed construction in terms of their LCAs. This research will be modelled towards this procedure by using concrete and timber for a duplex residential building.

\subsection{Method of environmental impact assessment}

Athena Impact Estimator software will be adopted for this research. It will be used to perform life cycle assessment of environmental impact of using concrete or timber to construct a duplex residential building [20]. The greenhouses gases to be monitored are $\mathrm{CO}_{2}$ equivalents, $\mathrm{SO}_{2}$ equivalents, phosphate equivalents and ethane equivalents.

\section{Environmental Impact Assessment Process}

The Environmental Impact assessment was carried out using the Athena Impact Estimator, which is capable of modeling 1,200 structural elements and envelope assembly combinations and providing a cradle-to-grave life cycle inventory profile for a whole building. The inventory results comprise the flows from and to nature, i.e., energy and raw material flows plus emissions to air, water and land. Building assemblies are designed and described through dialogue boxes that request simple data like bay sizes, loadings, concrete type etc. Bill of materials can also be imported directly from any CAD program. After modeling, the software calculates the associated environmental impacts.Fig. 1 shows the building assemblies for concrete and timber models and the elements under each assembly. 


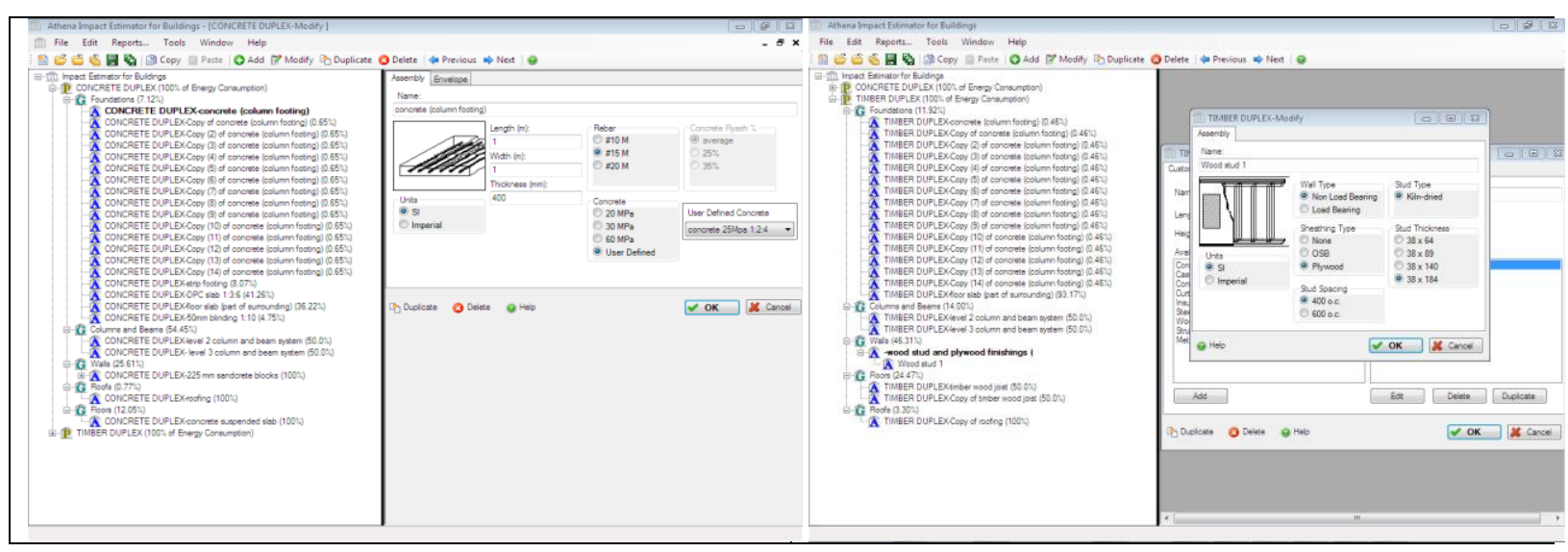

Figure 1: Users Interface of Athena Impact Estimator software.

\section{IV.}

Environmental Impact Results

\subsection{Comparison of Smog Potential}

The total smog potential of the concrete duplex throughout its life cycle is $2.46 \mathrm{e}+04 \mathrm{~kg} \mathrm{O}_{3}$ equivalent and that of the timber duplex is $7.34 \mathrm{e}+03 \mathrm{~kg} \mathrm{O}$ e equivalent which shows that the concrete duplex has approximately $235 \%$ more smog potential than that of the timber duplex throughout their respective life cycles. Fig. 2 shows the smog potential of the concrete and timber models, while figures 3 and 4 show smog potential of the concrete and timber model during construction process and the life cycle stages offuel consumption potential of the concrete and timber model respectively.

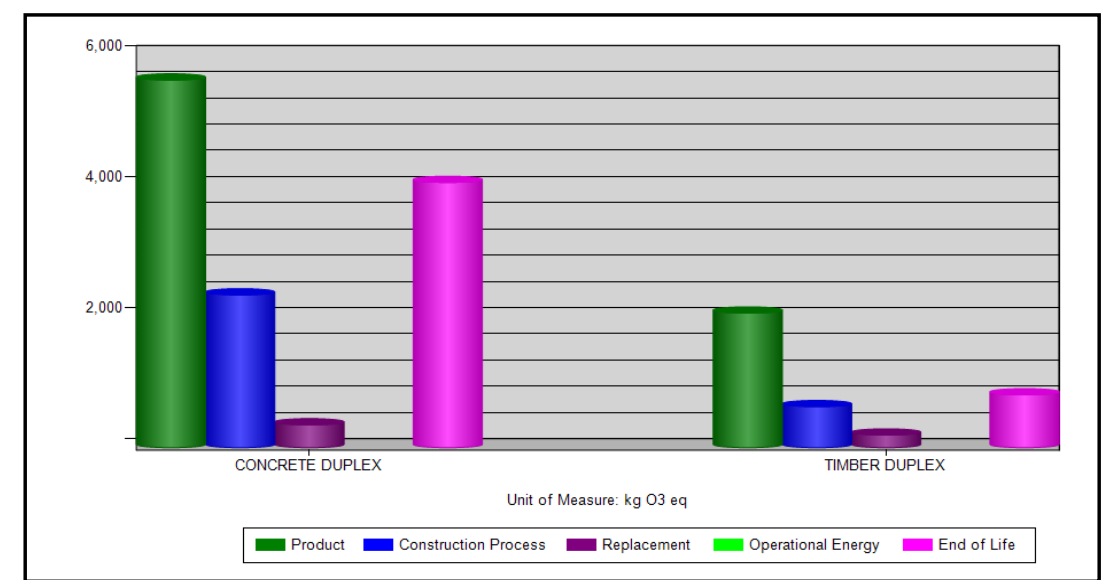

Figure 2:Life cycle stages ofsmog potential of the concrete and timber model.

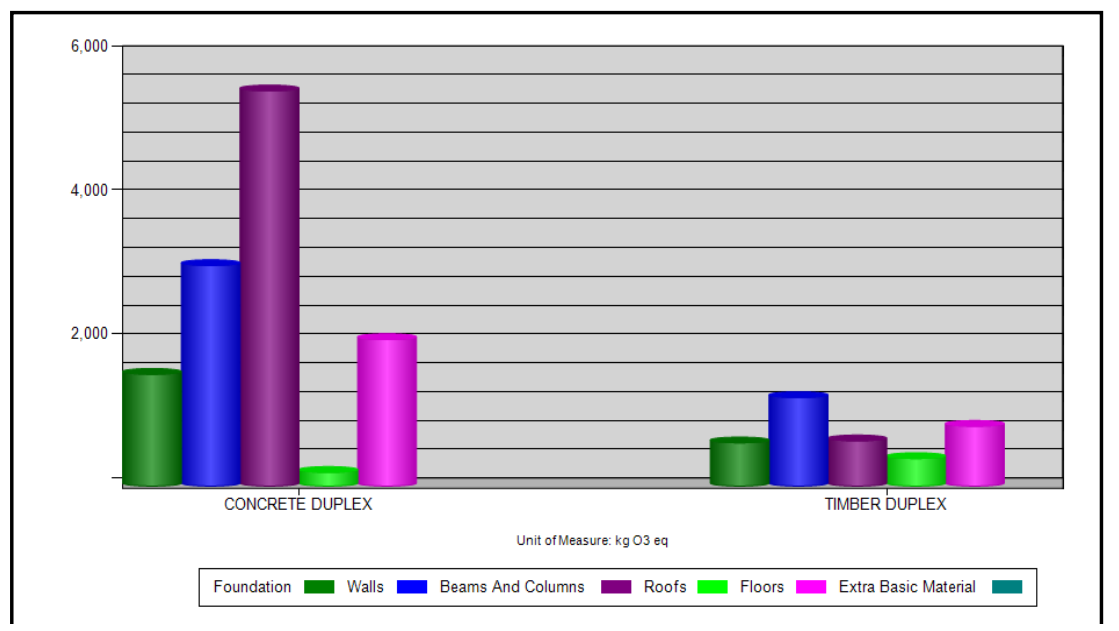

Figure 3: Smog potential of the concrete and timber model during construction process. 


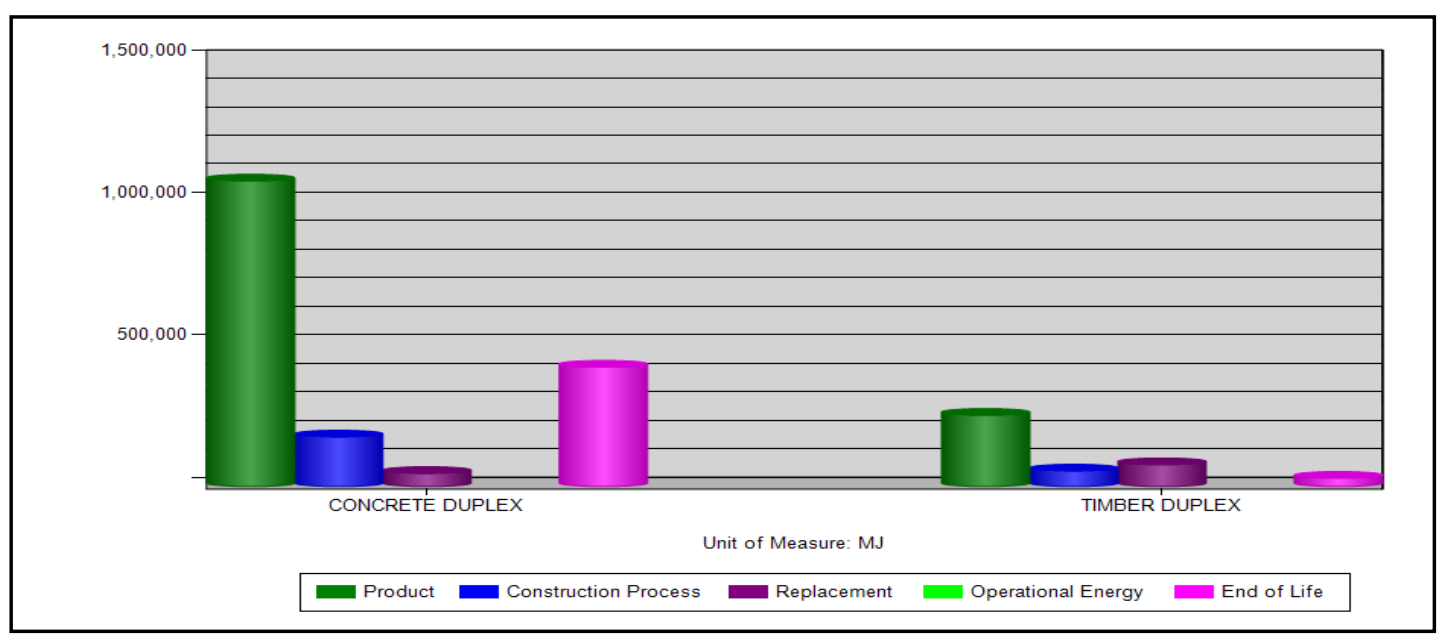

Figure4:Life cycle stages offuel consumption potential of the concrete and timber model.

\subsection{Comparison of Fossil Fuel Consumption}

The possible fossil fuel consumption potential of both models throughout their life cycles are compared, with the concrete model having fuel consumption values of approximately $1.71 \mathrm{e}+06 \mathrm{MJ}$ and that of the timber model being 4.12e+05 MJ. This result indicates a 315\% increase in fossil fuel consumption in the concrete model with respect to the timber's. This result indicates that more energy and fuel is consumed as regards concrete buildings in relation to timber buildings. Fig. 5 shows the fuel consumption potential of the concrete and timber model.

\subsection{Comparison of Ozone Depletion Potential}

The Ozone depletion potential in both models is highest during the materials production stage. The total ozone depletion potential of the concrete model is $5.69 \mathrm{e}-04 \mathrm{~kg} \mathrm{CFC}-11$ equivalent while that of the timber model is $1.46 \mathrm{e}-04 \mathrm{~kg}$ CFC-11 equivalent. This shows that the concrete model has approximately $290 \%$ more ozone depletion potential than that of the timber's.Figs. 6 and 7 show the ozone depletion potential for life cycle and for construction stage respectively.

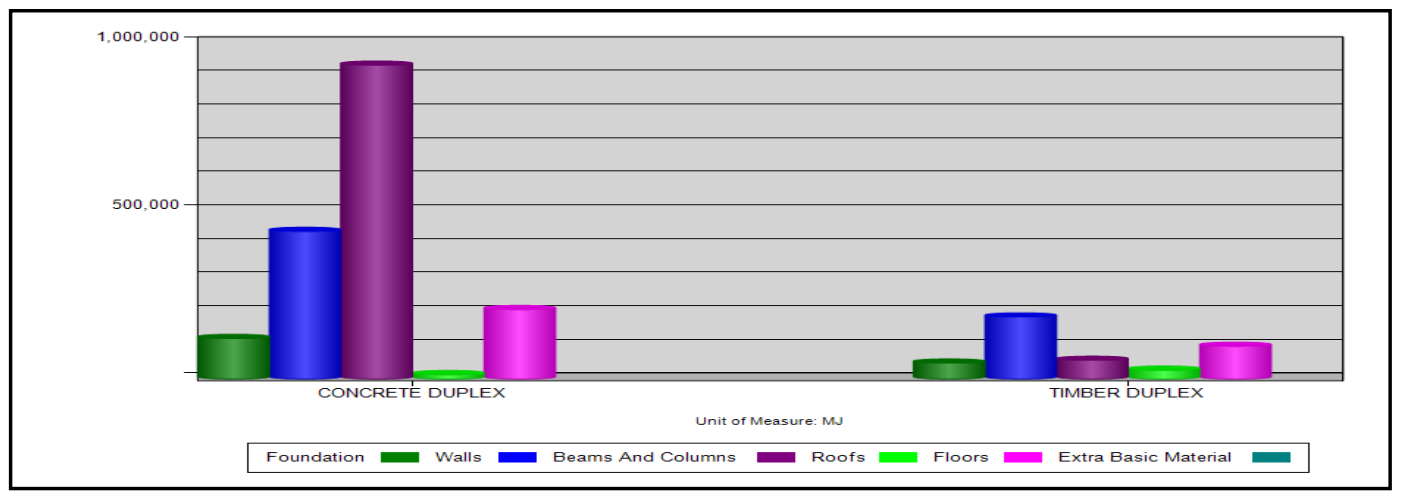

Figure 5: Fuel consumption potential of the concrete and timber model during construction.

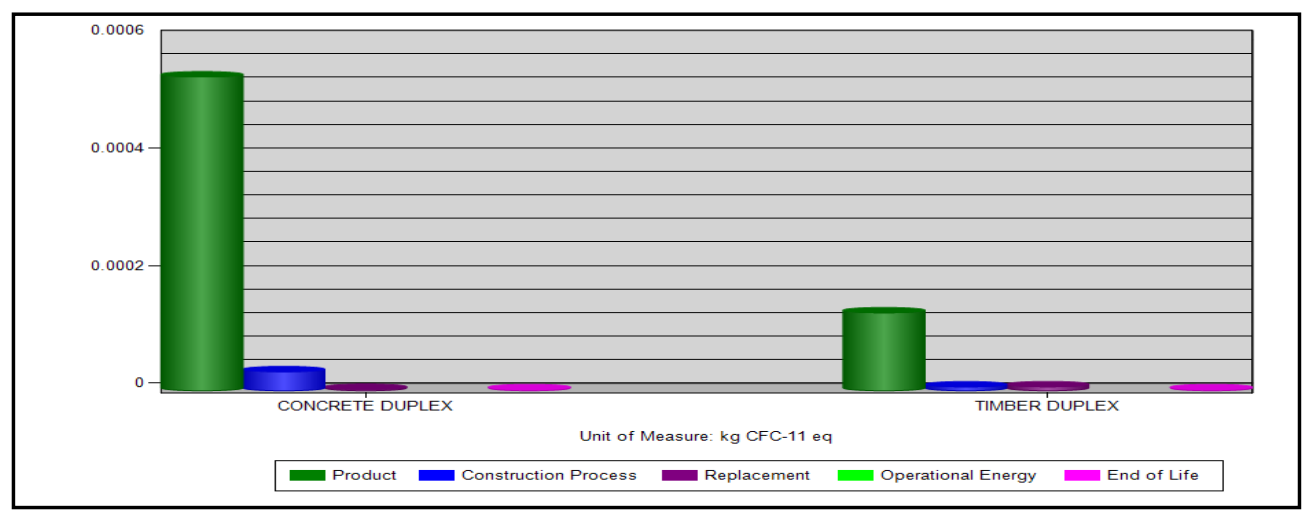


Figure 6:Life cycle stages ofozone depletion potential of the concrete and timber model.

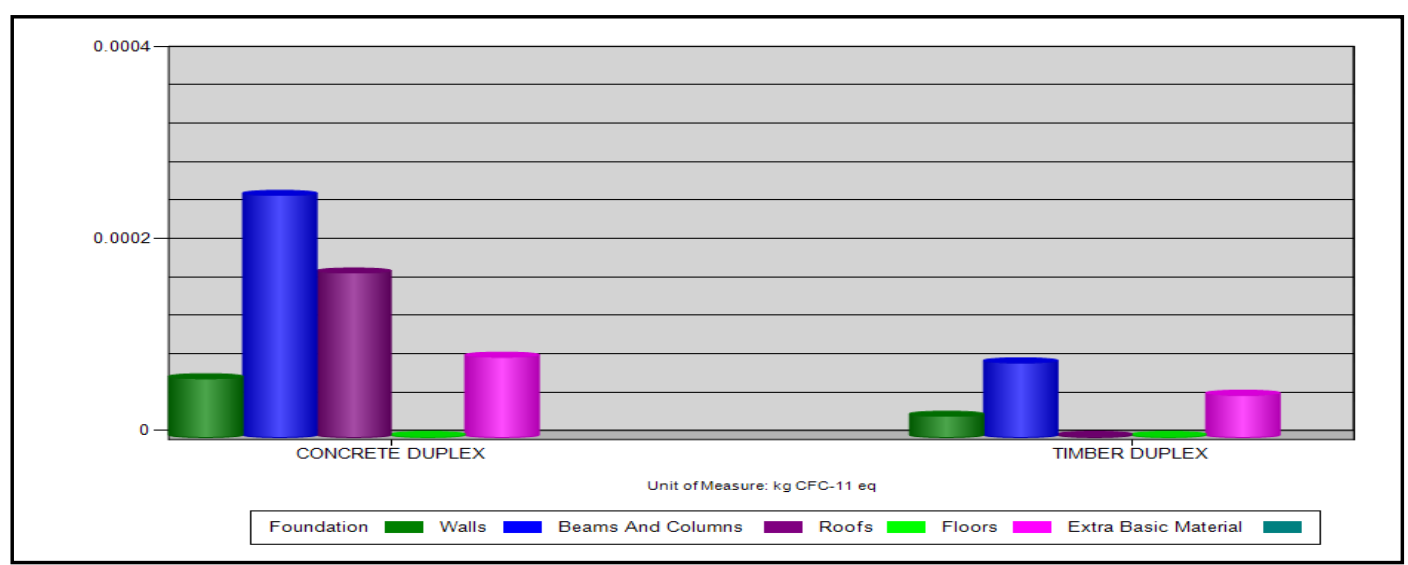

Figure 7:Ozone depletion potential of the concrete and timber model during construction.

\subsection{Comparison of Global Warming Potential}

The global warming potential of the concrete model is $1.81 \mathrm{e}+05 \mathrm{~kg} \mathrm{CO}_{2}$ equivalent while that of the timber model is $2.56 \mathrm{e}+03 \mathrm{~kg} \mathrm{CO}$ equivalent. This result indicates a higher global warming potential in the concrete models of up to $6,970 \%$ than that of the timber model. Figs. 8 and 9 show global warming potential of the concrete and timber model during the life cycle and the construction process respectively.

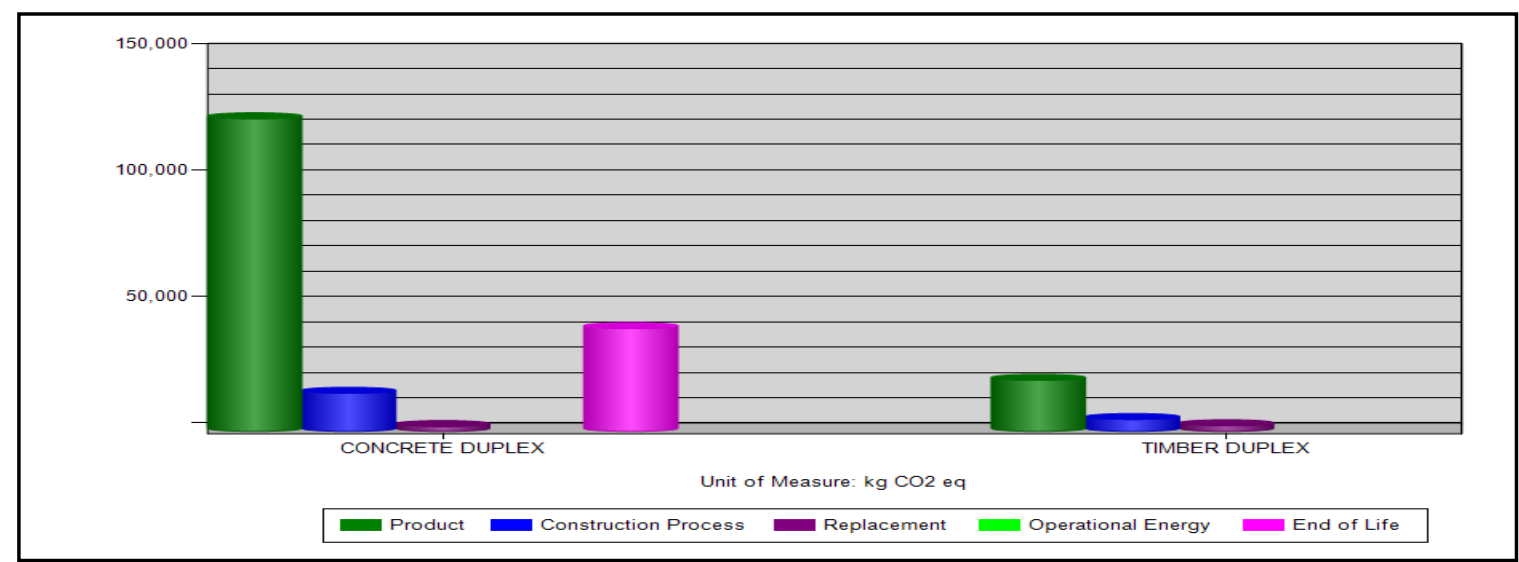

Figure 8:Life cycle stages of global warming potential of the concrete and timber model.

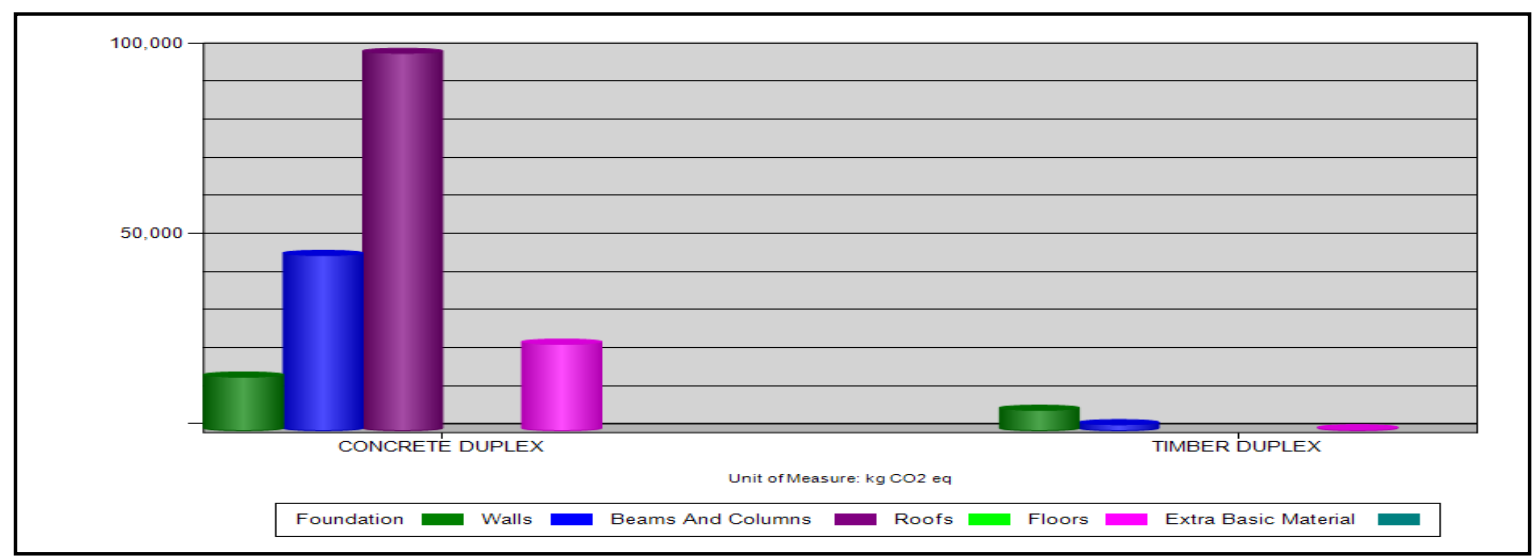

Figure 9: Global warming potential of the concrete and timber model during construction process. 


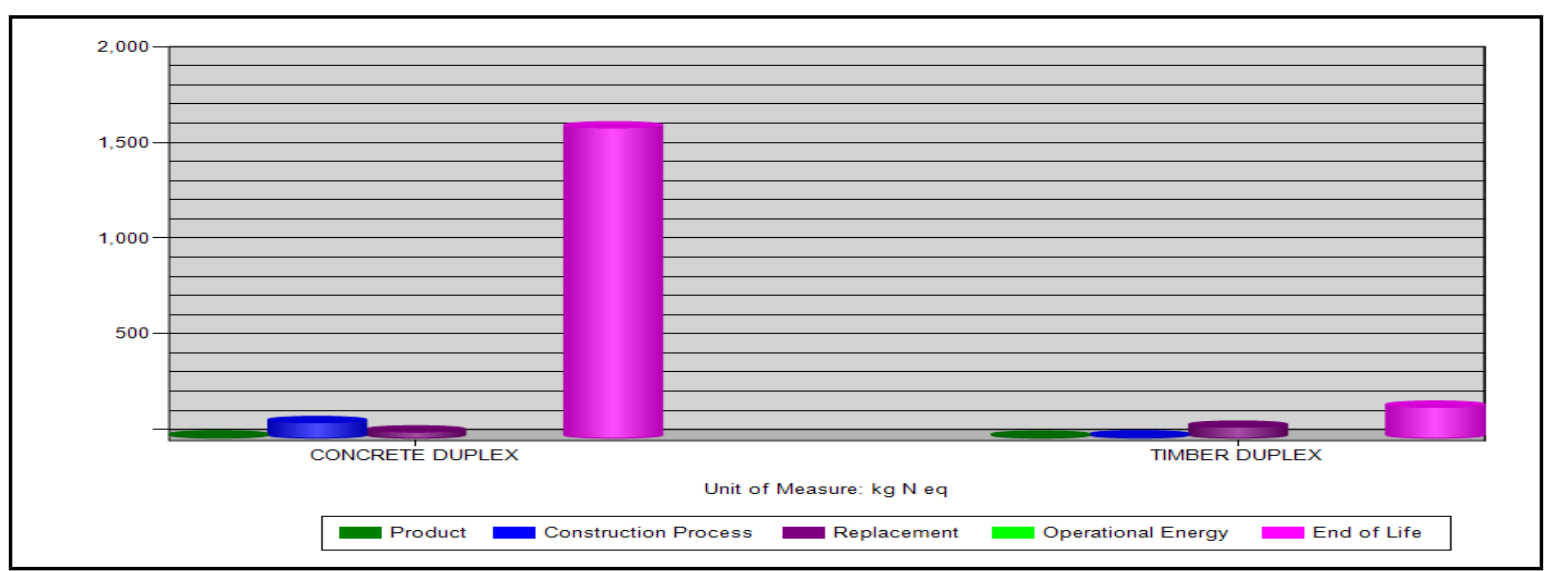

Figure 10:Life cycle stages of eutrophication potential of the concrete and timber model.

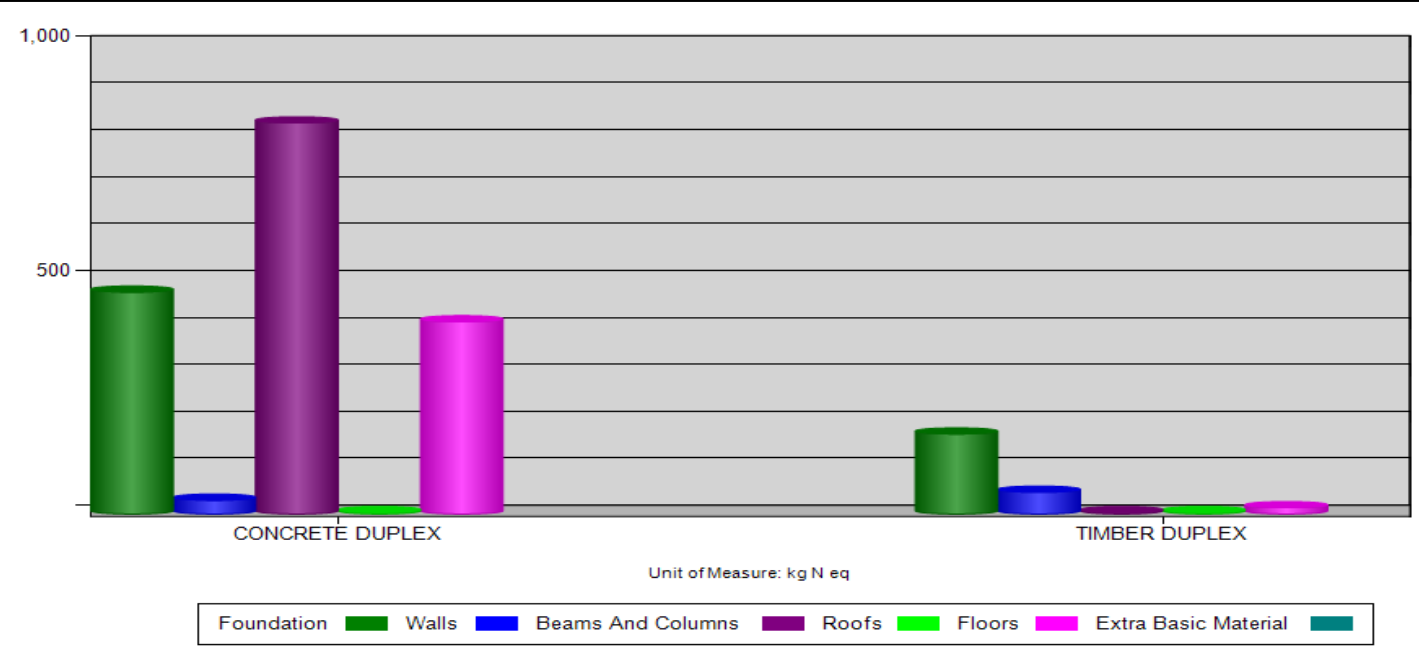

Figure 11: Eutrophicationpotential of the concrete and timber model during construction process.

\subsection{Comparison of Eutrophication Potential}

The total eutrophication potential of the concrete model throughout its life cycle is $4.49 \mathrm{e}+02 \mathrm{~kg} \mathrm{~N}$ equivalent while that of the timber model is $7.37 \mathrm{e}+01 \mathrm{~kg} \mathrm{~N}$ equivalent. The eutrophication potential of the concrete model is 509\% more than the timber model. Figs. 10 and 11 shows eutrophicationpotential of the concrete and timber model during the life cycle and construction process respectively.

\subsection{Comparison of Acidification Potential}

The total acidification potential of the concrete model is $7.71 \mathrm{e}+02 \mathrm{~kg} \mathrm{SO}_{2}$ equivalent while that of the timber model is $2.38 \mathrm{e}+02 \mathrm{~kg} \mathrm{SO}_{2}$ equivalent This result indicates a $324 \%$ increase in the concrete model with respect to the timber model. Figs. 12 and 13 show the acidification potential of the concrete and timber model during the life cycle and construction process respectively. 


\section{Life Cycle Assessment Of Environmental Impacts Of Using Concrete Or Timber To Construct A...}

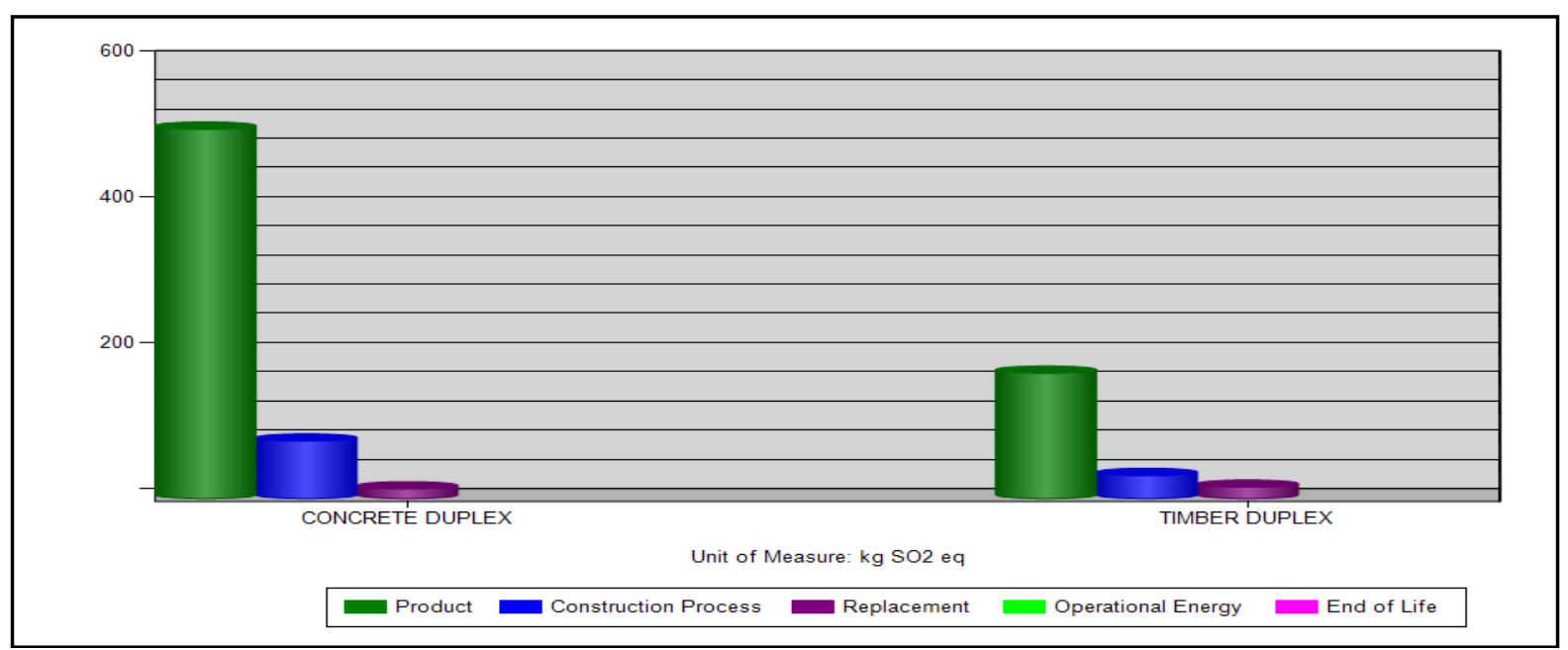

Figure 12:Life cycle stages of acidification potential of the concrete and timber model.

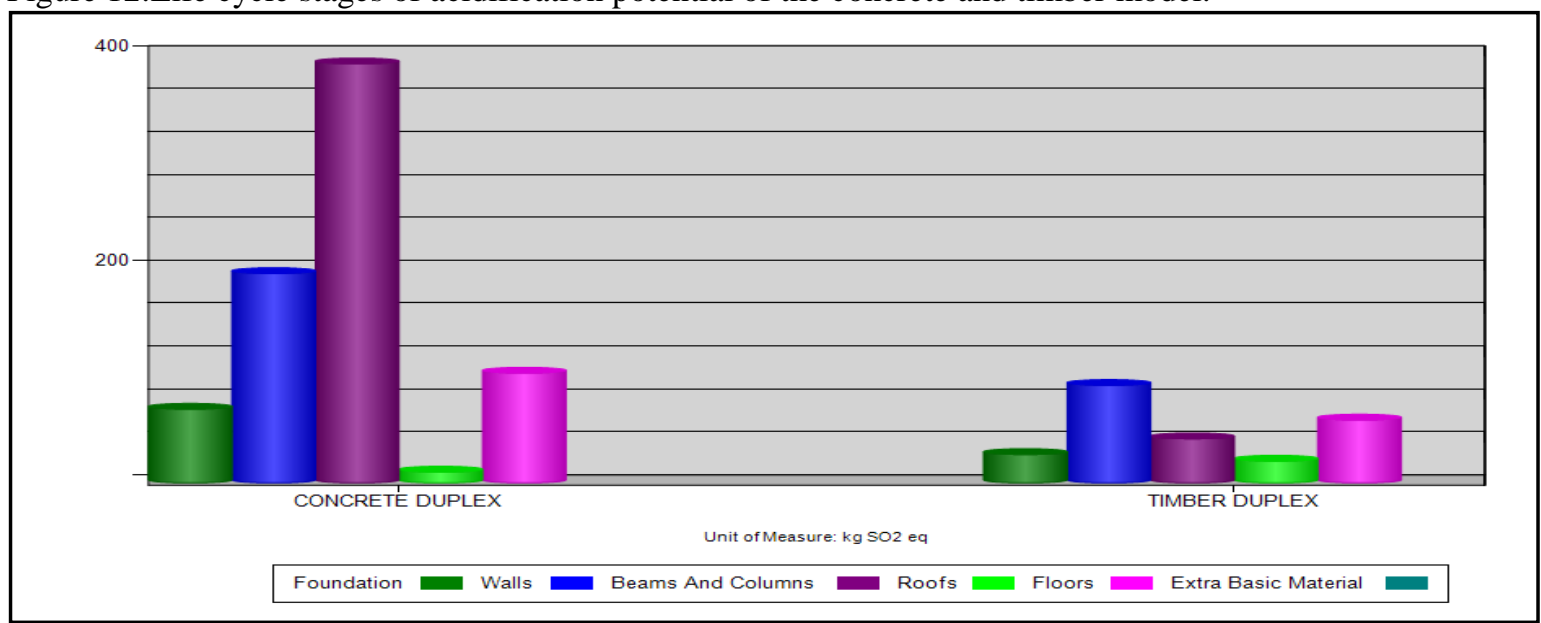

Figure 13: Acidificationpotential of the concrete and timber model during construction process.

\subsection{Waste production potential}

The estimated amount of resources and materials that constitute waste are shown below. Figs. 14 and 15 show the waste production potential of the concrete model during the life cycle and construction process respectively while Figs. 16 and 17 show the waste production potential of the timber model during the life cycle and construction process respectively.

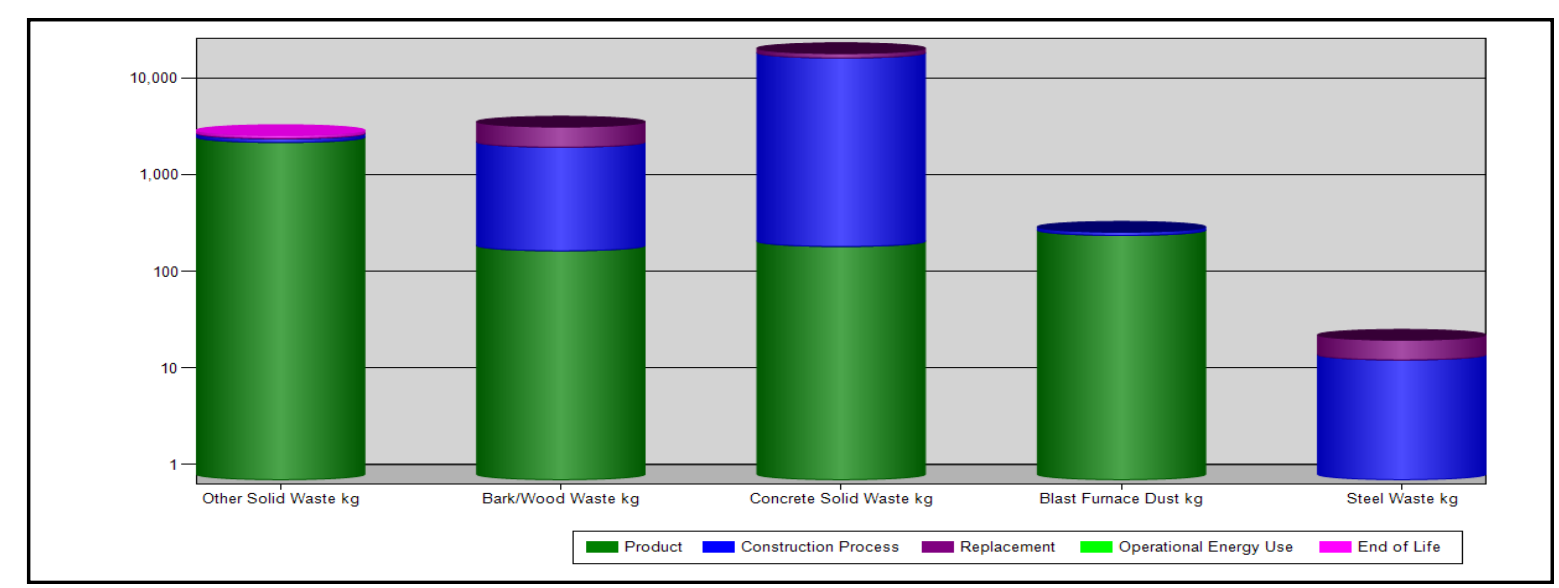

Figure 14:Waste produced in the various life cycle stages for the concrete model 


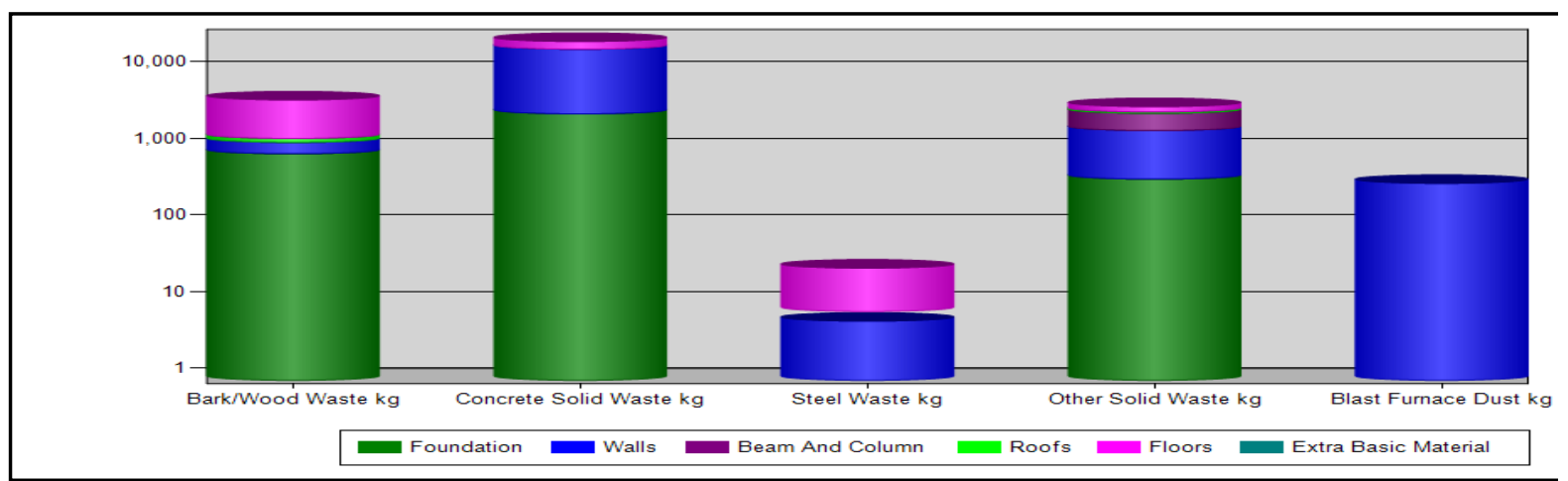

Figure 15:Waste produced in the various production stages for the concrete model

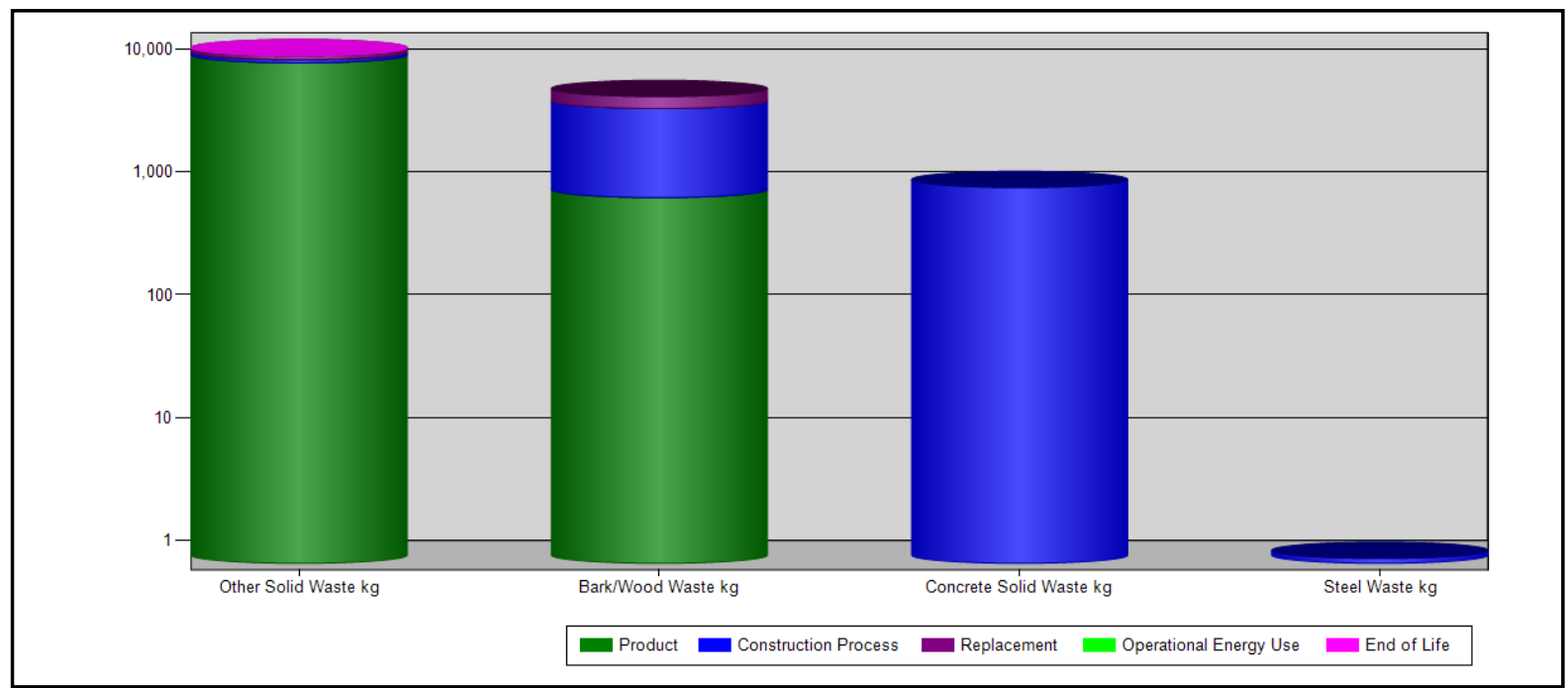

Figure 16: Waste produced in the various life cycle stages for the timber model

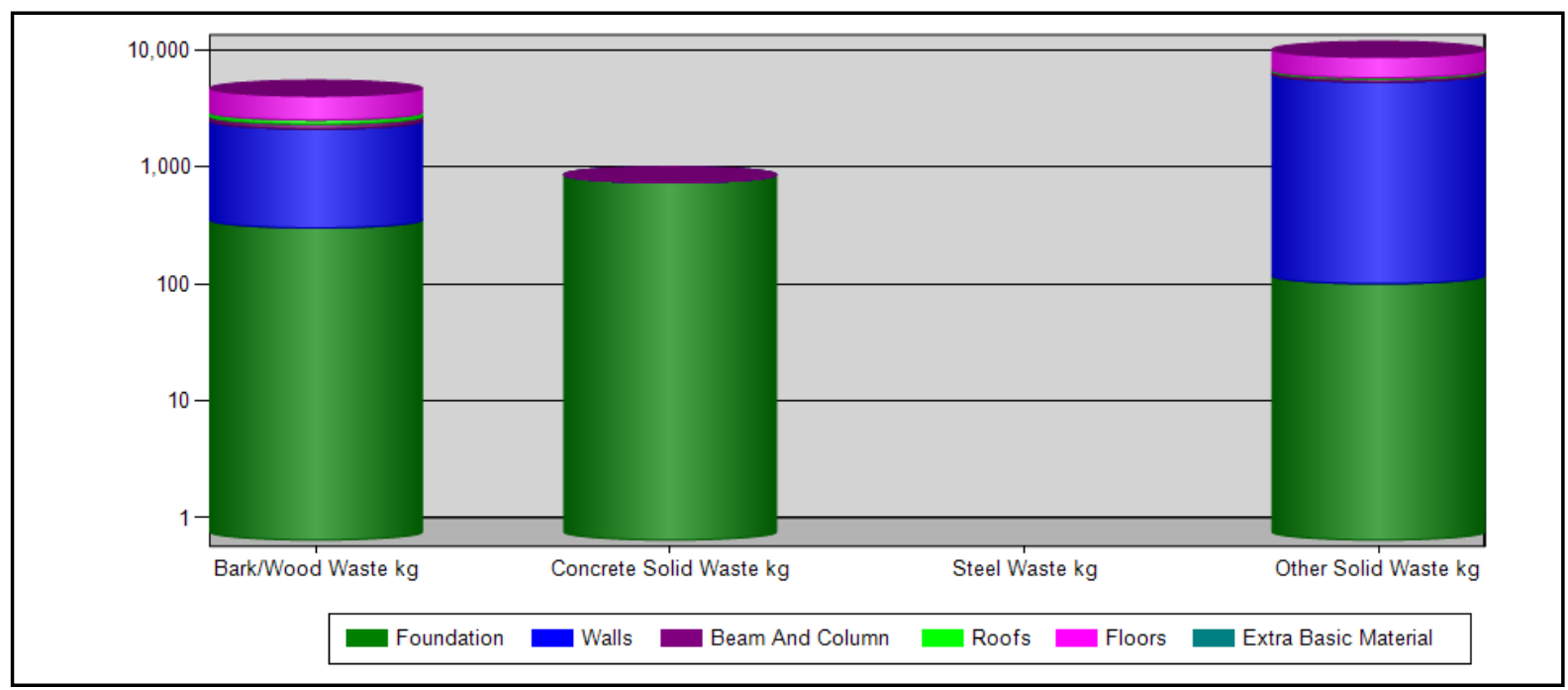

Figure 17: Waste produced in the various production stages for the timber model

\section{Conclusion And Recommendation}

From the various comparative tests and analysis carried out on both models of the environmental impact assessment, numerous results were obtained and showcased. From the various results gotten from the analysis, the timber model building appears more environmentally friendly when compared to the concrete model. This is largely due to the fact that timber has a positive impact towards reducing carbon emissions, and actively helps in storing atmospheric $\mathrm{CO}_{2}$ thereby reducing global warming. As regards heating and thermal 
insulation, concrete walls store heat during the day and release it back into the living ambient at night. This might be advantageous in the temperate regions, where much money and energy is consumed in relation to room and space heating, but in tropical regions like Nigeria, this creates heat dumping and uncomfortable spaces that need to be often air conditioned. Concrete homes don't naturally breathe and therefore hold moisture which can lead to unwanted health issues. Timber construction on the other hand allows the home to breathe by allowing air to pass through the walls while insulating heat and inhibiting vapor, making concrete homes certainly less energy efficient and less environmentally friendly. We therefore recommend more intensive research into domestication of timber material technology in the developing countries as such holds better all-round potential for affordable and environmental friendly residential homes for low income owners.

\section{References}

[1]. A.N. Ede and J.O.Okundaye, Appraisal of Timber as Structural Members for Residential Buildings in Nigeria, International Journal of Engineering \& Technology IJET-IJENS Vol:14 No:01,2014, pp.108-112.

[2]. C. Arya, Design of Structural Elements, Spon press270 Madison Avenue, New York, NY 10016, USA, 2009.

[3]. American Forest and Paper Association (AF\&PA), National Design Specification for Wood Construction and Supplement, 1991 ed., AF\&PA, Washington DC, 1991

[4]. Raw Materials Research and Development Council, RMRDC, Local Building and Construction Materials. Report of the MultiDisciplinary Task Force on the Survey and Update of the Report on Local Sourcing of Raw Materials for Building and Construction Industry inNigeria, 1998, pp. 27-39.

[5]. J. Köhler, Reliability of Timber Structures, Institute of Structural Engineering, Swiss Federal Institute of Technology, Zurich, 2007.

[6]. A. R. Fewell, Changes to the Requirements and Supply of Timber Structural Materials,UKTEG Seminar, I. Structural Engineering, London, (1997).

[7]. Cement Concrete and Aggregates Australia (CCAA), 2010. Sustainable Concrete Buildings, Briefing 13.

[8]. D. M. Roodman and N. Lenssen, A Building Revolution: How Ecology and Health Concerns are Transforming Construction, Worldwatch Paper 124, WorldwatchInstitute, Washington, DC, 1995.

[9]. B. Fardin, Y.H. Ding, D. Mahmud, Q. Astro, 2010. An Investigation into the Use of Wood vs. Steel and concrete in Construction of the New SUB, the University of British Columbia, 2010.

[10]. M.F. Ashby, Materials and the Environment', Elsevier Inc., Oxford, UK, 2012.

[11]. N. Mahasenan, S. Smith, K. Humphreys, Y. Kaya,"The Cement Industry and Global Climate Change: Current and Potential Future Cement Industry $\mathrm{CO}_{2}$ Emissions". Greenhouse Gas Control Technologies - 6th International Conference. Oxford: Pergamon, 2003, pp. $995-1000$

[12]. A. Samarin,"Wastes in Concrete:Converting Liabilities into Assests", in Ravindra K. Dhir, Trevor G. Jappy, Exploiting Wastes in Concrete: Proceedings of the International Seminar held at the University of Dundee, Scotland, UK, Thomas Telford, 1999 , p. 8.

[13]. A.A. Guggemos and A. Horvath, 'Comparison of Environmental Effects of Steel- and Concrete-Framed Buildings' ASCEJournal of Infrastructure Systems, 2005.

[14]. A.N. Ede and K. Oshiga, Mitigation Strategies for the Effects of Climate Change on Road Infrastructure in Lagos, International Journal of Science Commerce and Humanities, Vol. 2 No.1, pp. 173-184, 2014.

[15]. W.R. Lawson, Timber in building construction: Ecological implications, Research paper commissioned by the Timber Development Association (NSW) limited and the FWPRDC, 1996.

[16]. I. Ferguson, B. La Fontaine, P. Vinden, L. Bren, R. Hateley, andB.Hermesec, 'Environmental Properties of Timber", Research Paper commissioned by the Forest \& Wood Products Research \& Development Corporation, 1996.

[17]. J.A. Fuwape, Developments in Wood - based industries in Nigeria,Foresea Miyazaki 2, 1998, pp. 575-585.

[18]. FAO,Environmental and Energy Balances of Wood Products and Substitutes. Rome: FAO Townsend P., Wagner C., 2002, Timber as a Building Material - An environmental comparison against synthetic building materials, National Association of Forest Industries Ltd (NAFI) Review, (2002).

[19]. P. Townsend, C. Wagner,Timber as a Building Material - An environmental comparison against synthetic building materials, 2002.

[20]. S.O. Adebayo, A Comparative Study on the Use of Concrete and Timber as Structural Members for Residential Buildings in Nigeria. An unpublished Students Project, Department of Civil Engineering, Covenant University, Ota Nigeria, 2014. 